\title{
EFFECT OF FERTILIZATION AND MYCORRHIZATION ON GROWTH AND NUTRITIONAL STATUS OF CRANBERRY (VACCINIUM MACROCARPON AIT.) IN THE NURSERY
}

\author{
Zenia MICHAŁOJĆ*, Michał Koter \\ Department of Soil Cultivation and Fertilization of Horticultural Plants \\ University of Life Sciences in Lublin, str. Leszczyńskiego 58, 20-068 Lublin Poland
}

Received: April, 2014; Accepted: June, 2014

\begin{abstract}
Cranberry (Vaccinium macrocarpon Ait.) is a species that is becoming increasingly popular due to the health value and taste qualities of fruits. Studies on cranberry 'Pilgrim' were carried out in 2012-2013 in the nursery farm. Plants were grown in containers in open space. The effect of method of fertilization and application of mycorrhizal vaccine on the growth, development and nutritional status of plants during the first two years of cultivation in the nursery was evaluated. Fertilizer characterized by a controlled release of nutrients (CRF) - Osmocote 6M, agent with sustained-releasing components (SRF) - Hortiform pH, fertigation and fertilization using Hortiform $\mathrm{pH}$ combined with fertigation, were applied. The vaccine contained fungi of Hymenoscyphus sp. genus that are characteristic for Vaccinium genus. Significantly greater weight of plant shoots as well as nitrogen, phosphorus, potassium, calcium and magnesium contents were recorded in plants supplied with the mycorrhizal vaccine. A positive effect of slow-releasing fertilizers on plant weight and their chemical composition has been demonstrated, whereas plants fertigated developed lower mass of shoots and contained less nitrogen, phosphorus, potassium, calcium and magnesium.
\end{abstract}

Key words: cranberry, nutrition, mycorrhizae, fertilization, nursery

\section{INTRODUCTION}

Cranberry (Vaccinium macrocarpon Ait.) belongs to the Ericaceae family. An increased interest in cranberry is the effect in the taste and pro-health value of fruits. Fruits are recommended for the prevention of civilization diseases (cardiovascular diseases, cancer) due to the high content of antioxidants (Kaczmarczyk \& Zbeć 1998). On an industrial scale, cranberry is grown in North America, where its cultivation area is over 11000 hectares, while the annual yield is estimated at 150000 tons (Smolarz 2009). An increase of cranberry cultivation area is observed in Europe as well as in Poland; its cultivation is possible with using relevant agricultural technology, including a proper $\mathrm{pH}$ of the soil, irrigation and fertilization (Krzewińska \& Smolarz 2008).
Under natural conditions, cranberry grows on poor, acid soils, which are abundant in organic matter (Haffner 1993). The cranberry root system is devoid of root hairs and their role is replaced by mycorrhizal fungi (Roper \& Vorsa 1997). A join action of the fungus and root allows to increase the absorption of phosphorus (Myers \& Leeake 1996) and nitrogen (Kosola et al. 2007). It is assumed that mycorrhizal fungi are responsible for the decomposition of organic matter, which in the natural environment allows the plant to absorb nutrients (Read 1996).

In the nursery, both in the container cultivation as well as in the ground, the most common fertilizing method is the use of nutrients of controlled release (CRF) and the sustained release (SRF) (Chohura 2004). However, fertigation, which is the combination of fertilization with irrigation, becomes an increasingly common way to supply nutrients. This 
method was once reserved only for crops grown under covers, but now it replaces mineral fertilization partly or completely (Aendekerk 1997). The fertilizers can be applied through the capillaries or sprinkling.

The aim of this study was to determine the effect of fertilization method and ericoidal mycorrhiza application on growth and development as well as the degree of plant nutrition with nitrogen, phosphorus, potassium, magnesium and calcium, of 'Pilgrim' cranberry in the container cultivation.

\section{MATERIALS AND METHODS}

The experiments were carried out in the Ericaceae crop nursery "Majewscy" in Witowice near Końskowola (Lublin province $\varphi=51^{\circ} 24^{\prime} 34,91^{\prime}$ N, $\lambda=22^{\circ} 06^{\prime} 01,64^{\prime \prime}$ E) in 2012-2013.

The research material consisted of highyielded cranberry 'Pilgrim' cv. that was bred in 1930. The cultivar is characterized by strong growth, thick vegetative stems, long fruit-producing shots and medium sized, intensely green leaves. The fruits are very large, oval, covered with an abundant waxy coating. The skin is purple red with yellowish tint near the stalk. The pulp is firm and has great value for processing (Smolarz 2009).

The experiment was established as bi-factorial in a complete randomized system. One repetition was a single plant per container of capacity $0.5 \mathrm{dm}^{3}$ in the first year of study and $2.0 \mathrm{dm}^{3}$ in the second. Each combination was repeated 32 times.

The starting plants in the experiment were vegetatively propagated. Plants were grown in a peat substrate of $\mathrm{pH} 4.2$, with content of $\mathrm{N}$-min. and $\mathrm{P}$, $\mathrm{K}, \mathrm{Mg}$ less than $10 \mathrm{mg} \cdot \mathrm{dm}^{-3}$.

Influence of the following factors was studied:

\section{Fertilization}

1. Slow Release Fertilizer Hortiform pH (SRF) $17 \% \mathrm{~N} ; 3.5 \% \mathrm{P} ; 12.5 \% \mathrm{~K} ; 1.8 \% \mathrm{Mg} ; 0.01 \% \mathrm{~B}$; $0.01 \% \mathrm{Cu} ; 0.5 \% \mathrm{Fe} ; 0.1 \% \mathrm{Mn} ; 0.001 \% \mathrm{Mo}$; $0.01 \% \mathrm{Zn}$,

2. Controlled Release Fertilizer Osmocote 6M (CRF) $-15 \% \mathrm{~N} ; 3.9 \% \mathrm{P} ; 10.0 \% \mathrm{~K} ; 1.2 \% \mathrm{Mg}$; $0.03 \% \mathrm{~B} ; 0.05 \% \mathrm{Cu} ; 0.45 \% \mathrm{Fe} ; 0.06 \% \mathrm{Mn}$; $0.02 \% \mathrm{Mo} ; 0.02 \% \mathrm{Zn}$,
3. Fertigation - medium containing $\left(\mathrm{mg} \cdot \mathrm{dm}^{-3}\right)$ : $<14 \mathrm{~N}^{-N_{4}} ; 56 \mathrm{~N}_{4} \mathrm{NO}_{3} ; 15 \mathrm{P} ; 58 \mathrm{~K} ; 60 \mathrm{Ca}$; $12 \mathrm{Mg} ; 16 \mathrm{~S}-\mathrm{SO}_{4} ; 0.4 \mathrm{Fe} ; 0.3 \mathrm{Mn} ; 0.2 \mathrm{Zn}$; $0.06 \mathrm{Cu} ; 0.1 \mathrm{~B} ; 0.01 \mathrm{Mo}$ - applied once a week,

4. SRF (Hortiform $\mathrm{pH})+$ fertigation (SRF was applied only once, then fertigation every second week since May till September).

All combinations with fertilizer Hortiform $\mathrm{pH}$ and Osmocote $6 \mathrm{M}$ were applied once, when containers were filling with substrate in a dose of $3 \mathrm{~g} \cdot \mathrm{dm}^{-3}$, which gave the following amounts per whole vegetation season $\left(\mathrm{mg} \cdot \mathrm{dm}^{-3}\right): 450-510 \mathrm{~N}$; 105-120 P; 270-350 K; 36-54 Mg; 0.4 B; $1.0 \mathrm{Cu}$; 15.0 Fe; 3.0 Mn; 0.3 Zn; 0.3 Mo. Similar quantities of nutrients were supplied in a form of fertigation once per week, while in combined method Hortiform $\mathrm{pH}+$ fertigation, plants got by half of nutrients more than in other combinations.

\section{Mycorrhization}

1. Mycelium-inoculated plants $(\mathrm{M}+)$,

2. Plants without inoculation - control (M-).

Half of containers from each fertilizer combination was supplied with the mycorrhization vaccine before planting at a rate of $10 \mathrm{~cm}^{3}$ per plant (about 1000 propagation units) $(\mathrm{M}+)$, while the remaining ones were planted without mycorrhization (M-).

Mycorrhization vaccine used in the study originated from the Laboratory of Mycorrhizal Fungi Mykoflor and contained fungi of Hymenoscyphus sp. genus, which is known to live in symbiosis with Vaccinium genus.

The weight of annual shoots (leaves and stems) was determined in each year of study in the second decade of October.

The substrate samples for chemical analyses were collected in every year of the study in two terms: the first decade of August and the second decade of October using the short Egner's sticks. In every combination 20 single samples (about $0.5 \mathrm{dm}^{3}$ ) from vertical section of the container were collected (PN-R04028:1997). The extract in $0.03 \mathrm{M}$ $\mathrm{CH}_{3} \mathrm{COOH}$ was subjected for the determination of the content of $\mathrm{N}-\mathrm{NH}_{4}$ and $\mathrm{N}-\mathrm{NO}_{3}$ by means of Bremner distillation method with modification by Starck, $\mathrm{P}-\mathrm{PO}_{4}$ colorimetric vanado-molybdate 
method, $\mathrm{K}, \mathrm{Ca}$ and $\mathrm{Mg}$ - AAS method (PerkinElmer, Analyst 300), ${\mathrm{S}-\mathrm{SO}_{4}}_{4}$ applying nephelometry with $\mathrm{BaCl}_{2}$ and $\mathrm{Cl}$ with $\mathrm{AgNO}_{3}$ and set out $\mathrm{pH}_{(\mathrm{H} 2 \mathrm{O})}$ value measured potentiometrically and salts content conductometrically was expressed as the electrical conductivity (EC). Stems with leaves for analysis were collected every year in the first decade of August from each combination (approximately $100 \mathrm{~g}$ fresh weight) then dried at $65^{\circ} \mathrm{C}$ and grounded. After drying and grinding, total nitrogen was determined by Kjeldahl method in Kjeltec 2002 Distilling System Unit. After combustion of the plant material at a temperature of $200^{\circ} \mathrm{C}$, samples were 'dry' digested at a temperature of $450{ }^{\circ} \mathrm{C}$ and then treated with dilute hydrochloric acid in $1: 2$ ratio. Such prepared solutions were subjected to the determination of phosphorus, potassium, magnesium and calcium applying the same methods as for the substrate.

At the end of vegetation (October 2012 and 2013), the weight of one-year shoots was scored by cutting annual shoots from each of 32 plants in a treatment.

Statistical processing of the results was performed by means of analysis of variance for twofactorial experiment with a help of Artstar software using Tukey test at a significance level $\alpha=0.05$ to evaluate the differences. Every year analyses were conducted separately.

\section{Weather conditions}

The weather course in 2012-2013 was illustrated by the results obtained from the Meteorological Station IUNG in Puławy, located at a distance of $8 \mathrm{~km}$ from the site of experiments.

The year 2012 was characterized by mean air temperature $8.9{ }^{\circ} \mathrm{C}$, which was warmer than the multi-year by $1.2^{\circ} \mathrm{C}$. The average monthly air temperatures ranged from $-3.4{ }^{\circ} \mathrm{C}$ (January) to $21.4{ }^{\circ} \mathrm{C}$ (July). Year 2013 was warmer than the multiyear by $1.3{ }^{\circ} \mathrm{C}$; average temperature was $9.0^{\circ} \mathrm{C}$. It should be noted that March was extremely cold, as the long-term average temperature for this month was $1.6{ }^{\circ} \mathrm{C}$, while average temperatures in April, May, June, July, August and October were higher than the multiyear average values

Sum of precipitation in 2012 was $541 \mathrm{~mm}$, which was lower by $46 \mathrm{~mm}$ as compared to the longterm average, although during the vegetation
(March to November) it was $471 \mathrm{~mm}$, which was higher than the multi-year average. It indicates an uneven distribution of rainfalls. In 2013, the annual precipitation sum was $453 \mathrm{~mm}$ and it was lower by $88 \mathrm{~mm}$ as compared to the previous year. Higher precipitation sum in May 2012 and 2013 than for the long-term average, draws some attention. In contrast, a low amount of rainfall was recorded in October $(4 \mathrm{~mm})$ and the long-term average for this month is $47 \mathrm{~mm}$. The weather data show uneven distribution of precipitation and milder climate characterized by higher air temperatures.

\section{RESULTS}

The weight of annual cranberry shoots in the first year of cultivation in the nursery was $14 \mathrm{~g}$ per plant, on average and in the second year $22 \mathrm{~g}$ per plant. Regardless of the study year, significantly greater weight of shoots was obtained for plants inoculated with mycorrhizal vaccine (Table 1). Applied fertilization also had a significant impact on the weight of cranberry shoots. The largest weight was recorded after the application of SRF and CRF (Hortiform $\mathrm{pH}$ and Osmocote 6M). It should be emphasized that despite about half increased dose of nutrients, after using the Hortiform $\mathrm{pH}+$ fertigation, significantly lower weight of plants was observed, and the lowest after using only fertigation (Table 1). This relationship indicates that the single application of SRF and CRF is the preferred method of blueberry fertilization, while increasing dose of nutrients by half in the form of fertigation did not increase the biomass, conversely, its lowering was observed, similarly as in the case of fertigation.

Nutritional status of plants was evaluated based on the analysis of leaves, which were collected in the second decade of August. The average content of total nitrogen in two years of study ranged from 1.4 to $2.08 \% \mathrm{~N}$-tot., phosphorus $0.13 \% \mathrm{P}$, potassium $0.56-0.82 \% \mathrm{~K}$, calcium 0.35 $0.50 \% \mathrm{Ca}$ and magnesium $0.15-0.19 \% \mathrm{Mg}(\mathrm{Ta}-$ ble 2). Despite similar amounts of nutrients used in the two years of study, significant differences in the content of nitrogen, potassium, calcium and magnesium in plants were recorded between two years. It has been shown that application of mycorrhitic 
Table 1. Effect of type of fertilization and mycorrhization on fresh weight of annual shoots $\left(\mathrm{g} \cdot \mathrm{plant}^{-1}\right)$ in first and second year of cultivation

\begin{tabular}{|c|c|c|c|c|}
\hline \multirow{2}{*}{$\begin{array}{c}\text { Type of fertilization } \\
\text { (A) }\end{array}$} & \multirow{2}{*}{$\begin{array}{l}\text { Mycorrhizae } \\
\text { (B) }\end{array}$} & \multicolumn{3}{|c|}{$\begin{array}{l}\text { The average weight } \\
\text { of shoots per plant }\end{array}$} \\
\hline & & 2012 & 2013 & Mean \\
\hline Hortiform $\mathrm{pH}$ & M+ & 18 & 32 & 25 \\
\hline Osmocote & M+ & 21 & 20 & 21 \\
\hline Fertigation & M+ & 10 & 12 & 11 \\
\hline Hortiform $\mathrm{pH}+$ fertigation & M+ & 18 & 31 & 24 \\
\hline Mean for M+ & & 17 & 24 & 20 \\
\hline Hortiform $\mathrm{pH}$ & M- & 15 & 29 & 22 \\
\hline Osmocote & M- & 12 & 32 & 22 \\
\hline Fertigation & M- & 8 & 10 & 9 \\
\hline Hortiform $\mathrm{pH}+$ fertigation & M- & 11 & 11 & 11 \\
\hline Mean for M- (control) & & 11 & 20 & 16 \\
\hline \multirow{4}{*}{ Mean for type of fertilization } & Hortiform $\mathrm{pH}$ & 16 & 30 & 23 \\
\hline & Osmocote & 17 & 26 & 21 \\
\hline & Fertigation & 9 & 11 & 10 \\
\hline & Hortiform $\mathrm{pH}+$ fertigation & 14 & 21 & 18 \\
\hline General mean & & 14 & 22 & 18 \\
\hline \multirow{3}{*}{$\operatorname{LSD}_{0.05}$ for: } & Type of fertilization (A) & 3.13 & 3.73 & 5.84 \\
\hline & Mycorrhizae (B) & 1.66 & 1.98 & 3.12 \\
\hline & $\mathrm{A} \times \mathrm{B}$ & 5.31 & 6.33 & 9.80 \\
\hline
\end{tabular}

vaccine increased contents of nitrogen in leaves by $5.9 \%$, potassium by $14.0 \%$, calcium by $103.6 \%$ and magnesium by $6.2 \%$ as compared to plants without application of vaccine. Fertilization methods also significantly affected the content of individual nutrients in cranberries. The highest content of nitrogen, potassium, phosphorus and magnesium was found in plants fertilized with CRF (Osmocote 6M), slightly smaller in those fertilized with SRF (Hortiform $\mathrm{pH}$ ) and the lowest after the application of nutrients in the form of fertigation. Also, smaller amounts of nutrients in plants recorded in the leaves, where SRF (Hortiform $\mathrm{pH}$ ) + fertigation was used, as compared to the slow release fertilizer (Table 2).

The content of nutrients in the substrate, $\mathrm{pH}$ and salt concentration during the vegetation did not significantly differ between August and October, except for $\mathrm{Ca}$ and $\mathrm{Mg}$, although a tendency to decrease in October was evident (data not shown).

\section{DISCUSSION}

Biometric measurements showed a favorable effect of application of mycorrhizal vaccine and slow release fertilizers on one-year shoot weight. A similar dependence related to the beneficial effect of mycorrhization on the plant weight has been demonstrated by Stribley et al. (1975) and Read (1996). Kubiak (2007) emphasizes that mycorrhization allows the plant a better and faster adaptation to new conditions and is a kind of passive and active protection against root pathogens. The more, mycorrhization is performed only once for the entire life of the plant.

The optimum level of nutrition determines the strength of plant growth and development and in consequence the yielding. Cranberry is characterized by a poorly developed root system, thus symbiosis between the plant and mycorrhizal 


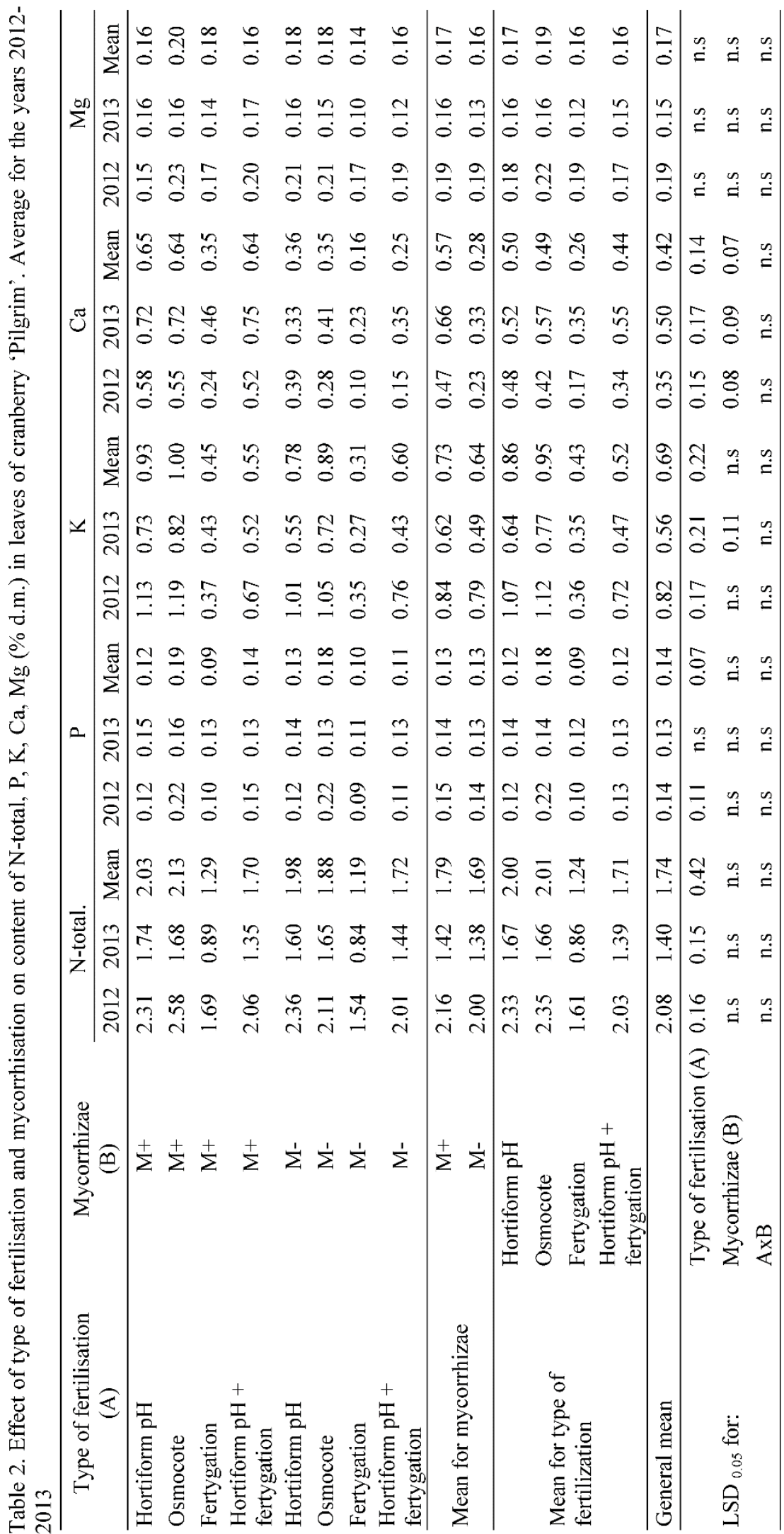


fungi improves the absorption of nutrients (Roper \& Vorsa 1997; Kosola et al. 2007). In the present study, the increase in nitrogen, phosphorus and magnesium contents by $6.6 \%$ on average, significant increase in potassium $(25.6 \%)$ and about twice higher calcium content, was demonstrated in plants inoculated with mycelium. According to Davenport, Provost (1994) as well as Myers and Leeake (1996), cooperation of mycorrhizal mycelium with roots promotes the uptake of nitrogen and phosphorus. This study clearly indicates an increased uptake of potassium and calcium in plants as well. Difference in the nutrient contents in leaves between the years of study, despite of the use of the same amount of nutrients, seems to be interesting. This dependence can be explained by variable weather conditions in particular years of experiment (Cummings 1978; Yadong 1998). The nitrogen content in leaves of cranberry after the application of variable fertilization ranged from $1.24 \%$ to $2.01 \% \mathrm{~N}$-total. Plants treated with higher doses of nitrogen, take in larger quantities of macroelements such as phosphorous and potassium (Davenport \& Provost 1994). According to Aendekerk (1997), the content of this component in leaves of healthy plants from Ericaceae family should be from 1.09 to $1.78 \% \mathrm{~N}$-total, whereas according to Davenport et al. (1995), this range is between $0.9 \%$ and $1.10 \% \mathrm{~N}$-total. On the basis of these values, it can be concluded that applied fertilization guaranteed an optimal level of plant nutrition with nitrogen.

The phosphorus content in cranberry leaves ranged from 0.09 to $0.18 \% \mathrm{P}$. The highest content was recorded using Osmocote $6 \mathrm{M}$ and the lowest using fertigation. According to Aendekerk (1997), the optimum phosphorus content in the leaves is $0.13-0.37 \% \mathrm{P}$, while the deficit symptoms were observed at $0.06-0.10 \%$ P. However, according to Davenport et al. (1995), optimum range is from 0.10 to $0.30 \%$ P. In the present study, the phosphorus content in cranberry leaves indicated the insufficient nutrition with this element.

The potassium content in plants ranged from 0.37 to $0.95 \% \mathrm{~K}$. A good supply with this component have been reported following the use of slow release fertilizer. Studies performed by Davenport et al. (1995) revealed that the optimum range for the content of potassium in cranberry is from 0.40 to $0.75 \%$ K. According to Aendekerk (1997), an appropriate level of potassium in leaves of nursery plants is from 1.1 to $2.35 \% \mathrm{~K}$ and its deficiency symptoms are observed when the content amounts to $0.19-0.72 \% \mathrm{~K}$. In the present study, applied fertilization led to an optimal supply of plants with this component only after the application of slow release fertilizers and mycorrhitic vaccine, however, the potassium deficiency symptoms have not been observed on the leaves of plants.

The calcium content in cranberry leaves ranged from 0.15 to $0.50 \% \mathrm{Ca}$. The largest contents of this element was found after the use of slow release fertilizer. The calcium content in leaves of well-nourished nursery plants, according to Aendekerk (1997), should be 0.45 to $0.80 \% \mathrm{Ca}$ and according to Davenport et al. (1995), from 0.30 to $0.80 \% \mathrm{Ca}$. Calcium nutritional status of plants that were fertilized with slow-release fertilizers (Hortiform $\mathrm{pH}$ and Osmocote $6 \mathrm{M}$ ) and combined fertilization (Hortiform $\mathrm{pH}$ along with fertigation) should be considered adequate. By contrast, the calcium content recorded in plants fertilized using fertigation should be considered critical $(0.15 \% \mathrm{Ca})$.

The magnesium content in cranberry leaves ranged from 0.15 to $0.19 \% \mathrm{Mg}$. According to Aendekerk (1997), this level should be considered as low for nursery plants and according to Davenport et al. (1975) as an optimum for cranberry. Proper magnesium content in the leaves of plants from $\mathrm{Er}$ icaceae family should be at the level of $0.20-0.60 \%$ $\mathrm{Mg}$ (Aendekerk 1997), while Davenport et al. (1975) reports $0.15-0.25 \% \mathrm{Mg}$ as the optimal range.

The nutrients in the substrate were determined twice: in full vegetation seasons and after its completion. According to Komosa and Breś (2012), standard macronutrient contents, $\mathrm{pH}$ value and salinity (EC) of the peat substrates for growing plants with low nutritional requirements in nurseries is $\left(\mathrm{mg} \cdot \mathrm{dm}^{-3}\right)$ : 100-130 N-min.; 30-50 P; 120-140 K; $1000 \mathrm{Ca}$; $30-50 \mathrm{Mg} ; \mathrm{pH} 4.6-5.2 ;<0.6 \mathrm{EC}\left(\mathrm{mS} \cdot \mathrm{cm}^{-1}\right)$. In the present study, values similar to the standard ones were present in August, which indicates the optimum for substrate and lower in October. The results show 
that plants uptake nutrients throughout the whole growing season, thus it is reasonable to use fertilizers with slow release of nutrients. Bosiacki et al. (2011) have shown a great usefulness of Osmocote type fertilizers for ornamental shrubs in nurseries.

Taking into account the size of produced biomass and optimum range of plant nutrition, it should be emphasized that applied slow-release fertilizers satisfy the nutritional requirements of cranberries, except for phosphorus, but fertigation requires further improvement of the fertilizer dose and application method.

\section{CONCLUSIONS}

1. Significantly greater weight of plants as well as nitrogen, phosphorus, potassium, calcium and magnesium contents was obtained in plants supplied with mycorrhizal vaccine.

2. Positive effect of slow release fertilizers on plants weight and their chemical composition, was observed, while plants fertilized using fertigation had lower weight and contained less nitrogen, phosphorus, potassium, calcium and magnesium.

3. Taking into account the size of produced biomass and optimum range of plant nutrition, it was found that applied slow-release fertilizers at the dose of $3 \mathrm{~g} \cdot \mathrm{dm}^{-3}$ fully satisfied the nutritional requirements of cranberries.

\section{REFERENCES}

Aendekerk T. 1997. Fertilization guide for nursery crops. Boomteelt Praktijkonderzoek, Boskoop, Netherlands.

Bosiacki M., Kleiber T., Markiewicz B. 2011. Estimation of the growth of selected taxons of ornamental shrubs depending on the fertilization with Osmocote Exact Standard (5-6 M). Nauka Przyroda Technologie 5(6): 1-13. (in Polish with English abstract)

Chohura P. 2004. Nawozy wolno działające dla produkcji szkółkarskiej. IX Ogólnopolska Konferencja Szkółkarska „Miejsce polskiego szkółkarstwa w Unii Europejskiej”. Skierniewice, pp. 55-59. (in Polish)
Cummings G.A. 1978. Plant and soil effects of fertilizer and lime applied to highbush blueberries. Journal of the American Society for Horticultural Science 105(6): 933-935.

Davenport J., DeMoranville C., Hart J., Patten K., Peterson L., et al. 1995. Cranberry tissue testing for producing beds in North America. Oregon State University Extension Service.

Davenport J., Provost J. 1994. Cranberry tissue nutrient levels as impacted by three levels of nitrogen fertilizer and their relationship to fruit yield and quality. Journal of Plant Nutrition 17(10): 1625-1634. DOI: 10.1080/01904169409364835.

Haffner K.E. 1993. Ecology of Vaccinium growing. Acta Horticulturae 346: 214-220. DOI: 10.17660/ActaHortic.1993.346.28.

Kaczmarczyk S., Zbeć I. 1998 Possibility of cultivating cranberries in Poland. Part II. Cranberry fruit usage. Folia Universitatis Agriculturae Stetinensis. Agricultura 69: 43-46.

Komosa A., Breś W. 2012. Kontrolowane żywienie roślin ogrodniczych. W: Żywienie roślin ogrodniczych. Podstawy i perspektywy. Powszechne Wydawnictwo Rolnicze i Leśne. pp. 325-364. (in Polish)

Kosola K., Workmaster B., Spada O. 2007. Inoculation of cranberry (Vaccinium macrocarpon) with the ericoid mycorrhizal fungus Rhizoscyphus ericae increases nitrate influx. New Phytologist 176(1): 184-196. DOI: 10.1111/j.1469-8137.2007.02149.x.

Krzewińska D., Smolarz K. 2008. The effect of nitrogen fertilization on American Cranberry (Vaccinium macrocarpon Ait.) production. Zeszyty Naukowe Instytutu Sadownictwa i Kwiaciarstwa 16: 135144. (in Polish with English abstract)

Kubiak J. 2007. Future technology of mycorrhization in horticultural mass production. Inżynieria Rolnicza 9(97): 73-78. (in Polish with English abstract)

Myers M.D., Leeake J.R. 1996. Phosphodiesters as mycorrhizal P sources. II. Ericoid mycorrhiza and the utilization of nuclei as a phosphorus and nitrogen source by Vaccinium macrocarpon. New Phytologist 132(3): 445-451. DOI: $10.1111 / \mathrm{j} .1469-$ 8137.1996.tb01864.x

Read D.J. 1996. The structure and function of the ericoid mycorrhizal root. Annals of Botany 77(4): 365-374. DOI: 10.1006/anbo.1996.0044.

Roper T.R., Vorsa N. 1997. Cranberry: Botany and Horticulture. In: Janick J. (Ed.), Horticultural Reviews, vol. 21, John Wiley \& Sons, Inc., Oxford, pp. 215249. DOI: $10.1002 / 9780470650660 . c h 7$. 
Smolarz K. 2009. Borówka i żurawina - zasady racjonalnej produkcji. Hortpress, Warszawa. 255 p.

Stribley D.P., Read D.J. Hunt R. 1975. The biology of mycorrhiza in the Ericaceae. V. The effects of mycorrhizal infection, soil type and partial soil-sterilization (by gamma-irradiation) on growth of cranberry
(Vaccinium macrocarpon Ait.). New Phytologist 75: 119-130. DOI: 10.1111/j.1469-8137.1975.tb01378.x. Yadong L. 1998. Nutrition status of blueberry cultured on various acid soil types of Changbai Mountain Areas in Northest China. Journal of Jilin Agricultural University 20(4): 33-37. 